\title{
MODELLING THE EFFECTIVENESS OF PPP ROAD INFRASTRUCTURE PROJECTS BY APPLYING RANDOM FORESTS
}

\author{
Rūta RUDŽIANSKAITĖ-KVARACIEJIENĖ, Rasa APANAVIČIENĖ, Adas GELŽINIS \\ Kaunas University of Technology, K. Donelaičio g. 73, LT-44029 Kaunas, Lithuania
}

Received 22 Apr 2014; accepted 23 Jul 2014

\begin{abstract}
Transport sector is very important for development of local economies, so it is intensively studied in different countries. Road infrastructure construction projects in many European countries are mainly carried out through various forms of Public-Private Partnership (PPP). Financial evaluation, private partner selection criteria, technical characteristics and very important focus of sustainable development components (environmental, social and economic) of PPP road infrastructure development projects are widely analysed in the scientific literature. Although many research studies were published for PPP road infrastructure projects efficiency assessment from different aspects, there have not been created assessment methodology with all key areas incorporated altogether. The authors provide an integrated PPP road infrastructure projects effectiveness modelling methodology by applying Random Forest technique. The developed methodology is recommended to be applied for PPP road infrastructure projects effectiveness prediction from the private and public sector perspectives.
\end{abstract}

Keywords: road infrastructure projects, public-private partnership, effectiveness evaluation, Random Forests.

\section{Introduction}

Public Private Partnership (PPP) is collaboration between public and private sectors based on a long term agreement which aims to provide services traditionally assigned to the competence of the public sector and to maintain the infrastructure necessary for the development of those services. The core principle of PPP is to achieve the best value for invested money basing on the experience of the private sector and risk-sharing between the parties involved. PPP schemes are widely used in different areas, such as waste collection and recycling, health care, education and transportation projects.

Researchers in many countries analyse road construction projects developed and implemented using PPP schemes, and assess their effectiveness from different perspectives and aspects. Sivilevičius and Vansauskas (2013), Radziszewski et al. (2014), Nejad et al. (2013), Vaitkus et al. (2012) proposed to evaluate technical parameters of road projects: length of the road, types of paving, traffic flows, road categories, traffic safety measures and other factors. Jasiūnienè and Čygas (2013) developed a road accident prediction model for national roads. Road safety should play an important role in the selection of alternatives, and safety aspects should be included in the decision-making process in the initial planning and design stage (Laurinavičius et al. 2012).
Akbiyikli (2013) analysed financial aspects of road projects and concluded, that investments, project duration and maintenance costs are the most important factors. Jiang et al. (2011) developed multiple-objective cash flow planning model - Pareto optimality efficiency network model, which considers typical banking instruments, the constraints of the financial market, the budget constraints, and retention of money. Ashuri et al. (2012) concluded that the net present value (NPV) approach is insufficient to measure the economic risk of BuildOwn-Transfer (BOT) road construction projects. The authors proposed Minimum Revenue Guarantee and Traffic Revenue Cap models, which take into consideration uncertainty about the future traffic demands. Liu and Wilkinson (2014) evaluated large-scale public venue developments and identified the following critical features: sound business case development; streamlined financial arrangements; robust tendering; effective governance structure and partnership-based consortium; and realistic risk allocation.

Wang et al. (2014) proposed probabilistic model for assessment of the risks associated with tunnelling and its likelihood to damage to existing properties. Practical application of the model demonstrated that the accurate assessment of tunnel construction risks helps to avoid the potential accidents. Whereas Clarke and Laefer (2014)

Corresponding author: Rūta Rudžianskaitė-Kvaraciejienè

E-mail: ruta.rudzianskaite@gmail.com 
analysed the construction risk of buildings adjacent to tunnelling works and proposed to incorporate both cultural and physical aspects of buildings into pre-construction risk assessment procedure. Xu et al. (2010) developed the fuzzy synthetic evaluation model for assessing the overall risk level associated with PPP projects and the risk level of the particular critical risk groups: government intervention; government maturity risk; economic viability risk; market environment risk; construction and operation risk; macroeconomic risk. Jin (2010) proposed theoretical framework and a support tool for decision making on risk allocation strategy between government and private agencies in PPP projects. Zavadskas et al. (2010) analysed risk assessment of construction projects and proposed to take into account goals and interests of all stakeholders. Subramanian et al. (2012) analysed the political dimension of cooperation between the partners. This study proposed risks and opportunities to cooperation framework and identified five general categories of risk perceived by decision makers: capacity and knowledge, accountability and voice, sovereignty and autonomy, equity and access, stability and support.

Chan et al. (2010) identified five underlying critical success factors for infrastructure development using PPP schemes: stable macroeconomic environment; shared responsibility between public and private sectors; transparent and efficient procurement process; stable political and social environment; judicious government control. Grasman et al. (2014) analysed the environmental component of sustainable development and found that public-private cooperation in the field of environmental impact assessment provides the best solutions and the optimal benefit of the public. Álvarez-Herranz and Martínez-Ruiz (2012) suggested an innovative technique based on panel data and accessibility indicators, which can quantify the plan's economic impact on regional development. Meda (2012) analysed the main land value capture mechanisms in relation to increased transport accessibility and identified direct and indirect impacts of land value of transport investments: access to urban externalities, access to social infrastructure, access to development infrastructure and on-site improvement. Adetola et al. (2011) critically reviewed approaches of public-private collaboration strategy for delivering sustainable infrastructure projects in the architecture, engineering and construction (AEC) sector. The authors identified and highlighted 10 vital areas related to successful delivery of sustainable infrastructure projects: relationships, trust, risk allocation, legal and regulatory framework, communication, technology, finance, skills/competence, globalisation/collaboration and market maturity.

Although private partners are mostly interested in measuring the financial performance of infrastructure construction projects, the technical performance part is also very important because technical decisions influence the investment amount and the technical risk of the project. From the perspective of the public sector, the project must first of all be beneficial to the general public; therefore sustainability performance is the most important in terms of environment, society and economy. Only when all three sustainability components are evaluated positively the project might be rated as sustainable.

Different authors made profound analysis of separate aspects of PPP projects, but a single underlying assessment model that incorporates the priorities of the public and private sectors has not been proposed.

\section{Theoretical model for effectiveness evaluation of PPP infrastructure construction projects}

The theoretical model to assess the expected effectiveness of PPP infrastructure construction projects developed by the authors incorporates the evaluation of technical and financial performance, the assessment of private partner selection and environmental, economic and social elements of sustainable development. The effectiveness of PPP infrastructure construction projects is assessed in two dimensions: private partner interests and interests of the public sector. The desired results are: Return on Investment (ROI) and financial success of the future project to the private partner and the societal advantages of developed objects/services to the society (private sector). PPP infrastructure construction project is considered efficient if it satisfies the objectives and desired benefits of both sectors. Based on that, different evaluation perspectives are presented interrelated in the model of PPP infrastructure project effectiveness evaluation (Fig. 1). Systemized assessment measures and criteria of specific project area were selected for every component of the model following the analysed scientific research literature. The developed model was applied for the assessment of PPP road infrastructure project effectiveness. A variety of mathematical techniques have been applied for PPP infrastructure projects modelling from different aspects. Traditional net present value (NPV) valuation techniques are used by the private partner and the public sector, because these methods show projected financial performance, which is important to both parties. Value for Money is the most popular approach in public sector as it demonstrates the generated object or service benefits to the public. Method of Real options is mostly used by the private partner to assess the different options for possible investment alternatives.

Expert evaluation and statistical analysis are used by both sectors to evaluate, compare and predict the preliminary project results. Game theory is primarily applied for the risk assessment. Nowadays, private partners are increasingly using more advanced and sophisticated methods of artificial intelligence: random forest (RF), neural networks (ANN), support vectors machine (SVM), fuzzy logic, genetic algorithms, etc. (Chou et al. 2013; Abdallah, Marzouk 2013; Jingzhu, Ng 2013; Yazdani-Chamzini 2014). These methods can solve quite complex tasks and forecast the future results even with only partial project information. 


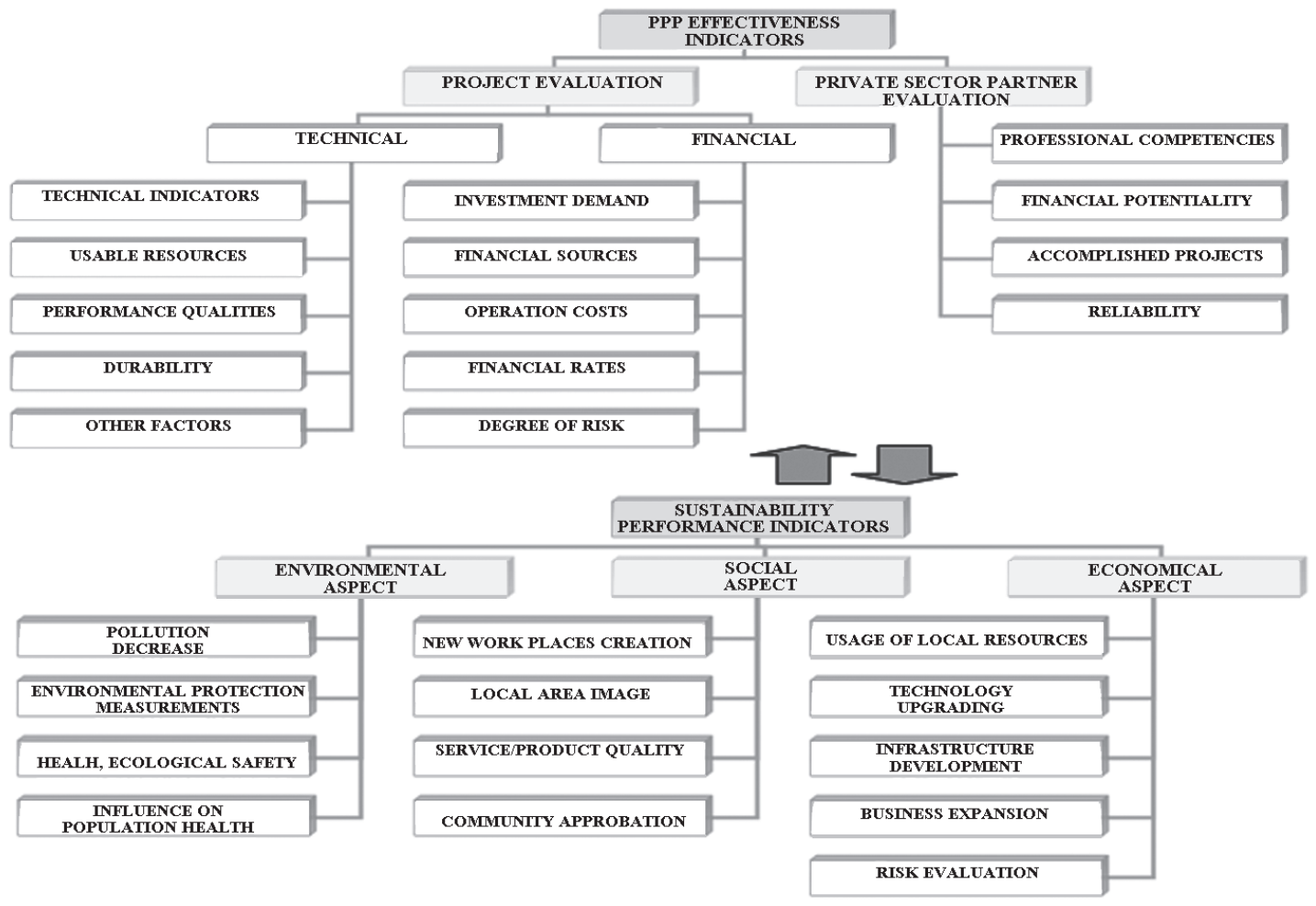

Fig. 1. Model of PPP infrastructure project effectiveness evaluation

Random Forest (RF) is comparably new (proposed by L. Breiman in 1996) and effective classification algorithm belonging to ensemble classification methods. Recently it has been very widely applied in biomedicine, image and sound recognition due to the large amount of data processing and a reliable and accurate assessment of the results. However, for the construction sector it is a novel approach. Based on the literature review RF application related to the construction sector was published by Antipov and Pokryshevskaja (2012), where RF technique was used for the mass appraisal of residential apartments.

The following strengths of RF method are listed in literature (Breiman 2001a, b):

- RF is one of the most accurate algorithms in the field of machine learning and artificial intelligence;

- RF enables efficient calculations of large databases;

- RF provides a possibility to make calculations with missing input variables without variable deletion;

- the obtained results show which variables are important for the decision in classification;

- the algorithm of RF method produces the generalization error, which enables to assess the accuracy and reliability of the method;

- RF contains error evaluation and balancing techniques that prevent the misbalance of input data.

Random Forest method was selected for the effectiveness modelling of PPP road infrastructure projects as one of the most accurate methods of artificial intelligence, which can solve the classification problems with a lot of variables and with a relatively small number of available data, and to provide reliable foresight results.

\section{Research database}

The empirical research database for the effectiveness modelling of road infrastructure projects developed using PPP scheme was compiled using the databases of European Investment Bank, European Bank for Reconstruction and Development, the World Bank, as well as road infrastructure websites and information from concessionaires, builders and operators of different European countries. The dataset consist of 74 PPP road infrastructure projects, developed mostly in EU. The following limitations were applied in developing the empirical research database:

- only construction projects from the transportation sector (roads, motorways, roundabouts) were selected;

- projects developed using PPP scheme;

- projects with completed construction phase;

- projects in operation for more than five years;

- main revenues of the projects are generated from tolling.

The range of PPP road infrastructure construction projects quantitative criteria is presented in Table 1.

The dataset of the projects was compiled based on the theoretical model and separate area assessment measures. Project effectiveness is assessed using technical, financial, private partner selection, environmental, social and economic measures. Based on the scientific literature review quantitative and/or qualitative criteria, listed in Table 2, were selected: criteria for the technical assessment of the project from $\mathrm{K} 1$ to $\mathrm{K}$ 9, criteria for financial assessment from K10 to K15 respectively; criteria for private partner assessment from K16 to K19. Sustainability was assessed in terms of environmental, social and 
Table 1. PPP road infrastructure construction projects quantitative criteria

\begin{tabular}{l|c|c}
\hline Quantitative criteria & Min value & Max value \\
\hline $\begin{array}{l}\text { Length of the newly constructed / } \\
\text { reconstructed road, km }\end{array}$ & 11.60 & 365 \\
\hline $\begin{array}{l}\text { Average annual daily traffic } \\
\text { (AADT) }\end{array}$ & 3300 & 300000 \\
\hline $\begin{array}{l}\text { Number of lanes (in each } \\
\text { direction) }\end{array}$ & 1 & 6 \\
\hline $\begin{array}{l}\text { Investments for the project, } \\
\text { thousands of EUR }\end{array}$ & 13 & 7625014 \\
\hline Concession duration, years & 78500 & 60000000 \\
\hline $\begin{array}{l}\text { Annual road maintenance costs, } \\
\text { thousands of EUR }\end{array}$ & 0.01 & 4.56 \\
\hline Average toll price, EUR/km & 0 & 6000 \\
\hline $\begin{array}{l}\text { Number of work places created } \\
\text { during the project lifetime }\end{array}$ & & \\
\hline
\end{tabular}

economic aspects with more detailed explanation below: qualitative criteria for environmental impact assessment from K20 to K25; criteria for social impact assessment from $\mathrm{K} 26$ to $\mathrm{K} 28$; criteria for economic impact assessment from K29 to K32.

\section{Modelling the effectiveness of PPP road infra- structure projects by applying Random Forests}

\subsection{Random Forests methodology}

A RF consists of decision trees that predict classes. A solution tree used in a RF is called CART - a classification and regression tree.

The main idea of building a RF is to build a precise classifier by joining the decisions of multiple ( $t$ in total) binary decision trees grown by using different subsets of data from the original data set $Z$, and randomly selected subsets of attributes (each of them has $q$ attributes) from the set of attributes $x_{1}, \ldots, x_{n}$. Such ensemble of binary trees is resistant to overtraining and relearning when the number of trees is growing. Generalization error converges to the stable limit when the number of trees increases (Breiman 2001a).

Using the database $Z$ consisting of $n$ observations and $p$ attributes, RF algorithm can be constructed by the following steps:

1. Select the forest size $t$ as the maximum number of tress and $q \leq p$ as the number of attributes to be used in each tree.

2. A sample, which is most often made of $\approx 2 / 3 n$ unique observations, is taken from $Z$ by means of repeated sampling, and $q$ attributes are selected at random.

3. The CART type tree is grown by using part of the data - the selected sample.

4. Steps 2 and 3 are repeated until the forest of $t$ trees is built.
Attributes for each tree in the forest are provided to classify the observation $x$ of unseen data and decisions are obtained. The obtained decision from each tree can be regarded to be a vote and the final decision is made by majority of votes.

Observations used in building the tree are memorized in the process of RF growing. Left out observations make the so-called out-of-bag (OOB) sample, which is successfully used to calculate the RF prediction error. To find the OOB error rate, each observation ( $x$ of the full data set sample $Z$ ) is classified only to those trees, during the growing of which the observation was not present.

The sum of class weights $w$ always equals to 1 . During the training the class weights are assumed distributed evenly between the classes. However, if the distribution between training data classes is different, weights of classes are calculated from the equation:

$$
w^{(k+1)}(n)=w^{(k)}(n) \beta_{k}^{d(n)} / \cdot \Sigma w^{(k)}(n) \beta_{k}{ }^{d(n)},
$$

where $w^{(k)}(n)$ is $k$-th step weight, o $\beta_{k}=\left(1-\varepsilon_{k}\right) / \varepsilon_{k}$ is error of weight assessment, $\varepsilon_{k}$ is class weight.

The decrease in accuracy and the Gini index are important indicators of result assessment in classification. The mean decrease in accuracy $R$ is calculated from the equation:

$$
R(d)=\frac{1}{N} \sum_{i=1}^{N} X\left(d\left(x_{n}\right) \neq j_{n},\right.
$$

where $X$ is the function indicator; $x=1$, when $X\left(d\left(x_{n}\right) \neq\right.$ $\left.j_{n}\right)$ is truth, $x=0$, when $X\left(d\left(x_{n}\right) \neq j_{n}\right)$ is untruth, and $d(x)$ is the classifier.

The Gini index $g$ is calculated from the equation:

$$
g(t)=\sum_{j i} p\left(\frac{j}{t}\right) p\left(\frac{i}{t}\right)=\sum_{j \neq i} C\left(\frac{i}{j}\right) p\left(\frac{j}{t}\right) p\left(\frac{i}{t}\right)
$$

where $p(j / t)$ is the probability of category $j$ at the node $t$, $c(i / j)$ is the probability of category $i$ in $j$ prediction probability.

$\mathrm{RF}$ predicts the error rate by the evaluation of the mean error. Computation error is referred to as the OOB classification error. Every RF calculation leaves $10 \%$ of input data unused, so there are $12.3 \%$ or almost $30 \%$ fewer than logistic regression errors (Breiman 2001b).

Computer assisted modelling was carried out using the RF Toolbox of MATLAB software.

\subsection{Project effectiveness modelling: the perspective of the private partner}

$\mathrm{RF}$ application algorithm for PPP road infrastructure project modelling is presented in Figure 2.

32 indicators (technical, financial, private partner selection, sustainability assessment in terms of environmental, social and economic aspects) listed in Table 2 are the input data $X$. The output data $Y$ is a generalized project 
Table 2. Quantitative and qualitative assessment criteria

\begin{tabular}{|c|c|c|c|c|c|c|c|c|c|}
\hline \multirow{2}{*}{ 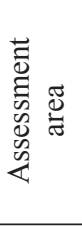 } & \multirow{2}{*}{ : } & \multirow[b]{2}{*}{ Criteria description } & \multicolumn{3}{|c|}{$\begin{array}{l}\text { Private partner's } \\
\text { perspective }\end{array}$} & \multicolumn{4}{|c|}{$\begin{array}{l}\text { Public partner's } \\
\text { perspective }\end{array}$} \\
\hline & & & 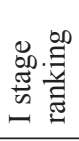 & 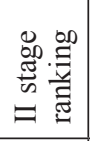 & 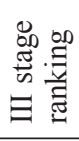 & 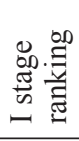 & 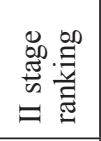 & 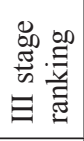 & 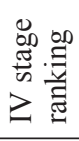 \\
\hline 1 & 2 & 3 & 4 & 5 & 6 & 7 & 8 & 9 & 10 \\
\hline \multirow{9}{*}{ 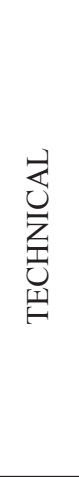 } & $\mathrm{K} 1$ & Length of the newly constructed/reconstructed road, km & 6 & 6 & 6 & 8 & 8 & 11 & 12 \\
\hline & $\mathrm{K} 2$ & Average annual daily traffic (AADT), number & 10 & 10 & 11 & 7 & 7 & 7 & 7 \\
\hline & $\mathrm{K} 3$ & Lanes (each direction), number & 25 & 25 & - & 13 & 13 & 13 & 13 \\
\hline & K4 & Type of road pavement, points $(0,1,2)$ & 31 & - & - & 30 & - & - & - \\
\hline & K5 & Road classification according to the category, points $(0,1,2,3)$ & 19 & 18 & - & 18 & $17-18$ & 18 & - \\
\hline & K6 & Structural complexity of the project, points $(0,1,2)$ & 21 & 21 & - & 22 & - & - & - \\
\hline & K7 & Toll collection system, points $(0,1,2)$ & 7 & 7 & 7 & 4 & 4 & 4 & 4 \\
\hline & K8 & $\begin{array}{l}\text { Material used for the road structures (viaducts, bridges, } \\
\text { tunnels), points }(0,1,2)\end{array}$ & 28 & - & - & 28 & - & - & - \\
\hline & K9 & Complexity of the project engineering systems, points $(0,1,2)$ & 24 & 24 & - & 20 & 15 & 14 & 14 \\
\hline \multirow{6}{*}{ 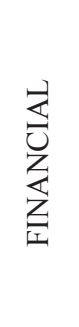 } & K10 & Investments for the project implementation, EUR & 5 & 4 & 5 & 3 & 3 & 3 & 3 \\
\hline & K11 & Project financing sources, points $(0,1,2)$ & 22 & 23 & - & 25 & - & - & - \\
\hline & K12 & Concession duration, years & 11 & 11 & 10 & 10 & 9 & 8 & 8 \\
\hline & K13 & Road exploitation expenses, $\%$ of the construction value & 4 & 5 & 4 & 6 & 6 & 6 & 6 \\
\hline & K14 & Average toll price, EUR $/ \mathrm{km}$ & 3 & 3 & 3 & 5 & 5 & 5 & 5 \\
\hline & $\mathrm{K} 15$ & $\begin{array}{l}\text { Risk distribution between the private and public sector, } \\
\text { points }(0,1)\end{array}$ & 26 & - & - & 29 & - & - & - \\
\hline \multirow{4}{*}{ 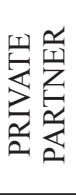 } & K16 & Competencies of the private partner, points $(0,1,2)$ & 14 & 14 & 15 & 16 & $17-18$ & 17 & 17 \\
\hline & K17 & Financial capacity of the private partner, points $(0,1,2)$ & 18 & 19 & - & 21 & - & - & - \\
\hline & K18 & Criterion of successfully implemented projects, points $(0,1,2)$ & 16 & 16 & 17 & 19 & 20 & - & - \\
\hline & K19 & Private partner risk management, points $(0,1,2)$ & 13 & 13 & 13 & 14 & 14 & 15 & 15 \\
\hline \multirow{6}{*}{ 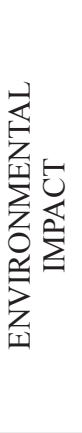 } & K20 & $\begin{array}{l}\text { Road safety measures installed during the project } \\
\text { construction, points }(0,1,2)\end{array}$ & 27 & - & - & 26 & - & - & - \\
\hline & K21 & Noise reduction instruments, points $(0,1,2)$ & 20 & 20 & - & 23 & - & - & - \\
\hline & K22 & $\begin{array}{l}\text { Traffic regulation and control measures installed during the } \\
\text { project construction, points }(0,1,2)\end{array}$ & 17 & 17 & 16 & 27 & - & - & - \\
\hline & K23 & $\begin{array}{l}\text { Surface water collection and wastewater treatment facilities } \\
\text { installed during the project construction, points }(0,1,2)\end{array}$ & 12 & 12 & 12 & 9 & 11 & 12 & 9 \\
\hline & K24 & $\begin{array}{l}\text { Urban landscape reconstruction after the project } \\
\text { construction, points }(0,1,2)\end{array}$ & 29 & - & - & 24 & - & - & - \\
\hline & $\mathrm{K} 25$ & Measures for wildlife protection installed, points $(0,1,2)$ & 15 & 15 & 14 & 15 & 16 & 16 & 16 \\
\hline \multirow{3}{*}{ 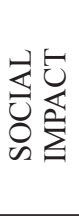 } & K26 & $\begin{array}{l}\text { Workplaces created during and after the project } \\
\text { implementation, number }\end{array}$ & 32 & - & - & 32 & - & - & - \\
\hline & K27 & Improvement of the local area image, points $(0,1,2)$ & 8 & 8 & 8 & 11 & 12 & 10 & 11 \\
\hline & K28 & $\begin{array}{l}\text { Reaction of the society on the land acquisition for public } \\
\text { use, points }(0,1,2)\end{array}$ & 9 & 9 & 9 & 17 & 19 & - & - \\
\hline \multirow{4}{*}{ 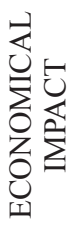 } & K29 & Usage of local resources (materials), points $(0,1)$ & 30 & - & - & 31 & - & - & - \\
\hline & $\mathrm{K} 30$ & Innovative solutions, points $(0,1,2)$ & 23 & 22 & - & 12 & 10 & 9 & 10 \\
\hline & K31 & Infrastructure development, points $(0,1,2)$ & 1 & 1 & 1 & 1 & 1 & 1 & 1 \\
\hline & $\mathrm{K} 32$ & Business development, points $(0,1,2)$ & 2 & 2 & 2 & 2 & 2 & 2 & 2 \\
\hline
\end{tabular}


effectiveness assessment measure taking into consideration the financial aspect based on the information provided by concessionaires and other parties about the project that was implemented in time without interruptions and delays, is successfully operated and most often was completed a few months before the anticipated contract time. Based on the aforementioned data $Y$ is divided into 2 classes:

- Class 1: financially unsuccessful project when the real cash flow was significantly lower than expected and PPP contract was terminated within five years since the start of the project. The database contains 7 unsuccessful projects.

- Class 2: financially successful project when the real cash flow was approximately equal to or higher than expected, the projects ran longer than five years. The database contains 67 successful projects.

Modelling objective was to create RF model for classifying all financially unsuccessful projects precisely by $100 \%$ and to reach the minimal OOB classification error for financially successful projects. RF parameters at the initial modelling stage were chosen as default settings recommended by RF methodology: number of forest trees ntree $=1000$, node splitting number mtry $=$ $\sqrt{32}$ and class weights cutoff $=0.5$ for Class 1 as well as for Class 2. By observing RF stability and seeking for the most accurate classification prediction, first of all

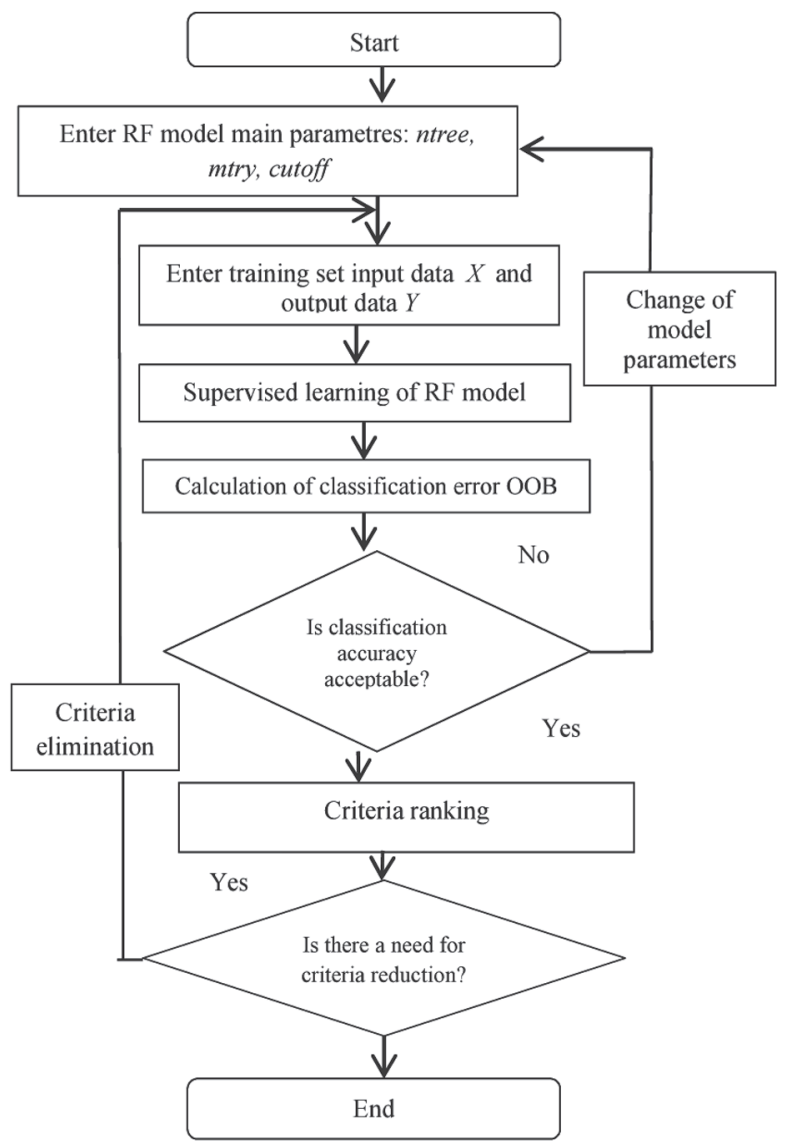

Fig. 2. RF application algorithm for PPP road infrastructure project modelling the number of forest trees ntree was determined by test track. Then the node splitting number mtry was reduced gradually by 1 , and finally the optimal class weights were identified by using readjustment step size 0.001 . At each step of all above mentioned alterations, RF computations were carried out for 10 times in order to check the RF model stability and OOB classification accuracy. Finally, the following parameters for initial stage of RF modelling were selected: number of forest trees $n$ tree $=10000$, node splitting number mtry $=2$, class weights cutoff for Class $1=0.1880$, for Class $2=0.8120$.

Stage I. The first modelling stage is carried out with 32 criteria. Calculation results are presented in Figure 3 and Figure 4. Priority ranking is presented in the $4^{\text {th }}$ column of Table 2. Classification error is $5.41 \pm 1.35 \%$. The least significant criteria taking places $26 \div 32$ in priorities line are left out.

Stage II. The Gini priority order with 25 criteria obtained in the modelling from private partner's perspective is presented in the $5^{\text {th }}$ column of Table 2. Classification error is $5.41 \pm 0.01 \%$. The least significant criteria taking places $18 \div 25$ in priorities line are left out.

Stage III. The third stage modelling is carried out with 17 criteria. The Gini priority ranking is presented in the $6^{\text {th }}$ column of Table 2. Classification error is $5.41 \pm 0.02 \%$. Classification error increases, if the number of criteria is further reduced, thus, this is the final RF

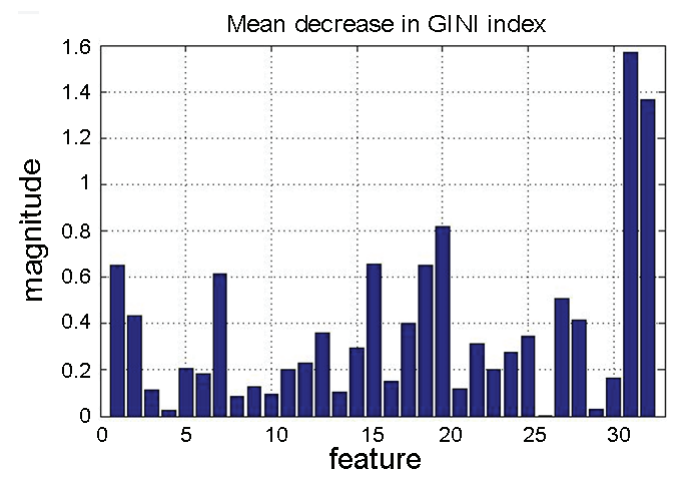

Fig. 3. Mean decrease in GINI index

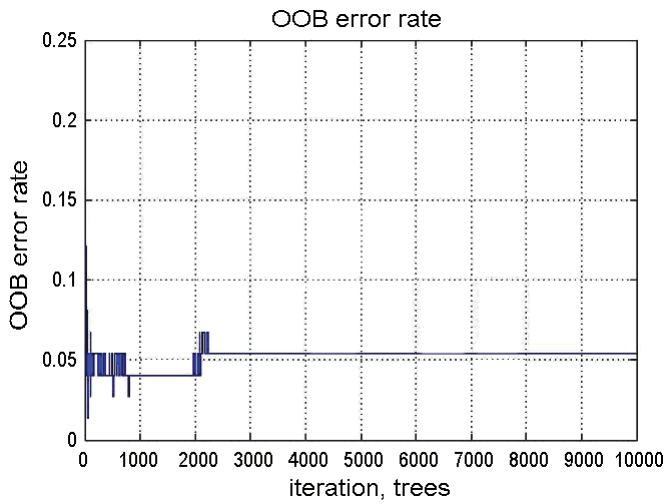

Fig. 4. OOB error rate 
model for PPP road infrastructure projects effectiveness from the perspective of the private sector.

\subsection{Project effectiveness modelling: the perspective of the public sector}

32 indicators (technical, financial, private partner selection, sustainability assessment in terms of environmental, social and economic aspects) listed in Table 2 are the input data $X$. The output data $Y$ is a generalized project effectiveness assessment measure taking into consideration the sustainability aspect according to the generalized output data of environmental, social and economic impacts. Based on the results of the three components, $Y$ is divided into 2 classes:

- Class 1: not sustainable projects when all three elements of sustainability (environmental, social and economic) have negative results or only one of the three elements has a positive result. There are 12 unsustainable projects in the database.

- Class 2: sustainable projects when all three elements of sustainability (environmental, social and economic) have positive results or at least two elements are evaluated positively. There are 62 sustainable projects in the database.

Modelling objective was to create RF model for classifying all not sustainable projects precisely by $100 \%$ and to reach the minimal OOB classification error for sustainable projects. By applying the same modelling procedures as described in Section 4.2, the following parameters for initial RF model were selected: number of forest trees ntree $=7000$, node splitting number $m$ try $=4$, class weights cutoff for Class $1=0.20$ and for Class $2=0.80$.

Stage I. RF modelling is carried out with 32 criteria. Classification error is $4.05 \pm 0.02 \%$. The priority order of the most significant criteria from the perspective of the public sector is presented in the $7^{\text {th }}$ column of Table 2. Criteria taking places $21 \div 32$ of the priority line are left out.

Stage II. The modelling from the perspective of the public sector with 20 criteria is run; the results are presented in the $8^{\text {th }}$ column of Table 2 . The priority order of criteria is made. The least significant criteria 19, 20 are left out. Classification error is $2.70 \pm 0.02 \%$.

Stage III. The modelling with 18 criteria is run; the results are presented in the $9^{\text {th }}$ column of Table 2. Classification error is $2.70 \pm 0.02 \%$. The least significant criteria 18 are left out.

Stage IV. The modelling with 17 criteria is run; the results are presented in the $10^{\text {th }}$ column of Table 2. Classification error is $1.35 \pm 0.02 \%$. Classification error increases, if the number of criteria is further reduced, thus, this is the final RF model for PPP road infrastructure projects effectiveness from the perspective of the public sector.

\section{Results and discussion}

Application of RF methodology was proved by comparison of RF with other two artificial intelligence techniques. In the initial phase the PPP road projects effectiveness modelling was carried out by applying random forests (RF), artificial neural networks (ANN), and support vector machines (SVM). Computer modeling was performed using RF, ANN, SVM Toolboxes of MATLAB software, by using the same input criteria $X$ presented in Table 2. Output data $Y$ was the same as described in Section 3.2 for project efficiency modelling from private partner perspective and the same as described in Section 3.3 for project efficiency modelling from public sector perspective. The classification errors were calculated for the test data. PPP road infrastructure projects' effectiveness modelling results are presented in Table 3. All three methods generated similar priority order of the most significant criteria, but the classification accuracy of RF was the highest, thus, RF method was selected for further calculations.

Table 3. PPP road infrastructure projects' effectiveness modelling

\begin{tabular}{l|c|c|c}
\hline $\begin{array}{l}\text { Classification error of } \\
\text { models from perspective } \\
\text { of private partner }\end{array}$ & RF & ANN & SVM \\
\cline { 2 - 4 } & $\begin{array}{c}5.41 \\
\pm 1.35 \%\end{array}$ & $\begin{array}{c}20,60 \\
\pm 0.01 \%\end{array}$ & $\begin{array}{c}28,44 \\
\pm 0.02 \%\end{array}$ \\
\hline $\begin{array}{l}\text { Classification error of } \\
\text { models from perspective } \\
\text { of public sector }\end{array}$ & \begin{tabular}{c} 
RF \\
\cline { 2 - 4 }
\end{tabular} & $\mathrm{ANN}$ & $\mathrm{SVM}$ \\
\hline
\end{tabular}

The final research results are based on two different RF models. RF models for financial and sustainability assessments differ by the following parameters: number of trees in random forests, number of attributes used for node splitting, stability of the forest, class weights and the number of output data criteria (Table 4).

The obtained modelling results from the perspective of the private partner confirmed the evaluation PPP road infrastructure project effectiveness model developed by the authors according to the key areas of assessment: technical and financial assessment of the project, the selection of the private partner and environment, social and economic components of sustainability as well as integrated assessment by 32 key quantitative and qualitative indicators of those areas. The 17 most significant criteria were

Table 4. The final research results

\begin{tabular}{l|c|c}
\hline RF model characteristics & $\begin{array}{c}\text { Private partner's } \\
\text { assessment } \\
\text { perspective }\end{array}$ & $\begin{array}{c}\text { Public sector } \\
\text { assessment } \\
\text { perspective }\end{array}$ \\
\hline RF tree number & 10000 & 7000 \\
$\begin{array}{l}\text { Number of randomly } \\
\text { selected variables at each } \\
\text { node }\end{array}$ & 2 & 4 \\
$\begin{array}{l}\text { Input variable number } \\
\text { Number of classes }\end{array}$ & 17 & 17 \\
Class weights: & 2 & 2 \\
$\quad$ Class 1 & 0.1880 & 0.20 \\
$\quad$ Class 2 & 0.8120 & 0.80 \\
RF stability (Number of & 2400 & 1600 \\
RF trees) & & \\
Classification error & $5.41 \pm 0.02 \%$ & $1.35 \pm 0.02 \%$ \\
\hline
\end{tabular}


Table 5. The priority order of the most significant criteria

\begin{tabular}{|c|c|c|c|c|c|c|}
\hline \multirow{2}{*}{ No. } & \multirow{2}{*}{$\begin{array}{l}\text { Assessment } \\
\text { area }\end{array}$} & \multirow{2}{*}{ Criteria } & \multicolumn{2}{|c|}{ Private partner perspective } & \multicolumn{2}{|c|}{ Public sector perspective } \\
\hline & & & Gini index & Priority order & Gini index & Priority order \\
\hline 1 & $\begin{array}{l}\text { Technical } \\
\text { assessment }\end{array}$ & $\begin{array}{l}\text { Length of the newly constructed/reconstructed } \\
\text { road } \\
\text { Average annual daily traffic (AADT) } \\
\text { Toll collection system } \\
\text { Lanes (each direction) } \\
\text { Complexity of the project engineering systems }\end{array}$ & $\begin{array}{l}0.8133 \\
0.4729 \\
0.6724 \\
- \\
-\end{array}$ & $\begin{array}{l}6 \\
11 \\
7 \\
- \\
-\end{array}$ & $\begin{array}{l}0.3029 \\
0.4467 \\
0.7511 \\
0.2540 \\
0.2172\end{array}$ & $\begin{array}{c}12 \\
7 \\
4 \\
13 \\
14\end{array}$ \\
\hline 2 & $\begin{array}{l}\text { Financial } \\
\text { assessment }\end{array}$ & $\begin{array}{l}\text { Investments for the project implementation } \\
\text { Concession duration } \\
\text { Road exploitation expenses } \\
\text { Average toll price, EUR/km }\end{array}$ & $\begin{array}{l}0.8400 \\
0.4885 \\
0.8654 \\
1.0368\end{array}$ & $\begin{array}{c}5 \\
10 \\
4 \\
3\end{array}$ & $\begin{array}{l}0.7959 \\
0.3643 \\
0.5066 \\
0.5998\end{array}$ & $\begin{array}{l}3 \\
8 \\
6 \\
5\end{array}$ \\
\hline 3 & Private partner & $\begin{array}{l}\text { Competencies of the private partner } \\
\text { Criterion of successfully implemented projects } \\
\text { Private partner risk management }\end{array}$ & $\begin{array}{l}0.3275 \\
0.2784 \\
0.3979\end{array}$ & $\begin{array}{l}15 \\
17 \\
13 \\
\end{array}$ & $\begin{array}{c}0.1154 \\
- \\
0.1718\end{array}$ & $\begin{array}{l}17 \\
- \\
15\end{array}$ \\
\hline 4 & $\begin{array}{l}\text { Environmental } \\
\text { impact }\end{array}$ & $\begin{array}{l}\text { Traffic regulation and control measures } \\
\text { installed during the project construction } \\
\text { Surface water collection and wastewater } \\
\text { treatment facilities installed during the project } \\
\text { construction } \\
\text { Measures for wildlife protection installed }\end{array}$ & $\begin{array}{l}0.3066 \\
0.4238 \\
0.3554\end{array}$ & 16 & $\begin{array}{c}- \\
0.3213 \\
0.1160 \\
\end{array}$ & - \\
\hline 5 & $\begin{array}{l}\text { Economical } \\
\text { impact }\end{array}$ & $\begin{array}{l}\text { Innovative solutions } \\
\text { Infrastructure development } \\
\text { Business development }\end{array}$ & $\begin{array}{c}- \\
2.1034 \\
1.8798\end{array}$ & $\begin{array}{l}- \\
1 \\
2\end{array}$ & $\begin{array}{l}0.3137 \\
8.1341 \\
6.1278 \\
\end{array}$ & $\begin{array}{c}10 \\
1 \\
2\end{array}$ \\
\hline 6 & Social impact & $\begin{array}{l}\text { Improvement of the local area image } \\
\text { Reaction of the society on the land } \\
\text { acquisition for public use }\end{array}$ & $\begin{array}{l}0.5496 \\
0.5416\end{array}$ & $\begin{array}{l}8 \\
9\end{array}$ & $\begin{array}{c}0.3040 \\
-\end{array}$ & $\begin{array}{c}11 \\
-\end{array}$ \\
\hline
\end{tabular}

selected for the future classification of the projects into two classes: unsuccessful and successful projects in terms of financial performance. The model for project sustainability assessment was developed to classify the problem into two classes: not sustainable and sustainable projects.

The obtained calculation results proved theoretical considerations of the authors to assess road projects in an integrated manner not only by environmental, social and economic elements of sustainability, but also by technical and financial evaluation as well as by the selection of the private partner. The classification of the projects into sustainable and not sustainable demonstrated that the level of sustainability is directly related with the technical characteristics of the project, and the final result of the project also depends on the competent private partner, whose experience and risk management guarantees the success and sustainability of the project.

The most important assessment of the future project performance from the perspectives both of the private partner and the public sector is the integrated assessment by the major assessment areas, namely technical, financial, private partner selection, environmental, social and economic. The priority order of the most significant criteria from the private partner's and the public sector perspectives are presented in Table 5 .

\section{Conclusions}

1. PPP infrastructure construction projects are recommended to be assessed in the integrated manner through the evaluation of financial, technical, private partner selection criteria, as well as sustainability aspects by using PPP effectiveness evaluation model proposed by the authors.

2. Project effectiveness evaluation model takes into consideration two aspects of assessment, namely the private partner perspective and the perspective of the public sector.

3. Novel approach of RF methodology was successfully applied for the effectiveness modelling of PPP road infrastructure modelling.

4. Calculation results confirmed PPP road infrastructure project effectiveness evaluation model developed by the authors according to the following key areas of assessment: technical and financial assessment, private partner selection and environmental, social and economic elements of sustainability. In the assessment of project performance from the perspectives of the private partner and the public sector the following priority order of key criteria was established: infrastructure development, business development, average toll price, road maintenance costs, project investments, road length, toll collection system, improvement the image of the local area, concession time, average annual daily traffic, surface water collection and wastewater treatment facilities, private partner's risk management, measures for wildlife protection installations, competencies of the private partner. Traffic regulations and control measures installations during the projects 
construction criterion of successfully implemented projects by the private partner and reaction of the society on the land acquisition for public use are also important for the private partner. Number of road lanes and project engineering systems complexity criteria are important for the public partner.

5. RF model developed by authors is recommended to use in the early stage of feasibility studies for the future prediction of PPP road infrastructure projects effectiveness from the perspective of private partner as well as the public sector.

\section{References}

Abdallah, M.; Marzouk, M. 2013. Planning of tunneling projects using computer simulation and fuzzy decision making, Journal of Civil Engineering and Management 19(4): 591-607. http://dx.doi.org/10.3846/13923730.2013.793608

Adetola, A.; Goulding, J.; Liyange, C. 2011. Collaborative engagement approaches for delivering sustainable infrastructure projects in the AEC sector: a review, International Journal of Construction Supply Chain Management 1(1): 1-24. http://dx.doi.org/10.14424/ijcscm101011

Akbiyikli, R. 2013. Performance assessment of a private finance initiative road project. Lithuanian road safety solutions based on intelligent transport systems, Transport 28(1): 11-24.

http://dx.doi.org/10.3846/16484142.2013.778899

Álvarez-Herranz, A.; Martínez-Ruiz, M. P.2012. Evaluating the economic and regional impact on national transport and infrastructure policies with accessibility variables, Transport 27(4): 414-427.

http://dx.doi.org/10.3846/16484142.2012.753641

Antipov, E. A.; Pokryshevskaja, E. B. 2012. Mass appraisal of residential apartments: an application of Random Forest for valuation and a CART-based approach for model diagnostics, Expert Systems with Applications 39(2): 17721778. http://dx.doi.org/10.1016/j.eswa.2011.08.077

Ashuri, B.; Kashani, H.; Molenaar, R.; Lee, S.; Li, J. 2012. Risk - Neural Pricing approach for evaluating BOT highway projects with government minimum revenue guarantee options, Journal of Construction Engineering and Management 138(4): 545-557. http://dx.doi.org/10.1061/(ASCE)CO.1943-7862.0000447

Breiman, L. 2001a. Random Forests, Machine Learning 45(1): 5-32. http://dx.doi.org/10.1023/A:1010933404324

Breiman, L. 2001b. Statistical modelling: the two cultures, Statistical Science 16(3): 199-231. http://dx.doi.org/10.1214/ss/1009213726

Chan, A. P. C.; Lam, P. T. I.; Chan, D. W. M.; Cheung, E.; Ke, Y. 2010. Critical success factors for PPP in infrastructure developments: Chinese perspective, Journal of Construction Engineering and Management 136(5): 484-494. http://dx.doi.org/10.1061/(ASCE)CO.1943-7862.0000152

Chou, J.-S.; Tsai, C.-F.; Lu, Y. H. 2013. Project dispute prediction by hybrid machine learning techniques, Journal of Civil Engineering and Management 19(4): 505-517. http://dx.doi.org/10.3846/13923730.2013.768544

Clarke, J. A.; Laefer, D. F. 2014. Evaluation of risk assessment procedures for buildings adjacent to tunnelling works, Tunnelling and Underground Space Technology 40: 333342. http://dx.doi.org/10.1016/j.tust.2013.10.014

Grasman, S. E.; Faulin, J.; Lera-López, F. 2014. Integrating environmental outcomes into transport Public-Private Partnerships, International Journal of Sustainable Transportation 8(6): 399-422.

http://dx.doi.org/10.1080/15568318.2012.708820
Jasiūnienè, V.; Čygas, D. 2013. Road accident prediction model for the roads of national significance of Lithuania, The Baltic Journal of Road and Bridge Engineering 8(1): 6673. http://dx.doi.org/10.3846/bjrbe.2013.09

Jiang, A.; Issa, R. R. A.; Malek, M. 2011. Construction project cash flow planning using the Pareto optimality efficiency network model, Journal of Civil Engineering and Management 17(4): 510-519. http://dx.doi.org/10.3846/13923730.2011.604537

Jin, X.-H. 2010. Determinants of efficient risk allocation in privately financed public infrastructure projects in Australia, Journal of Construction Engineering and Management 136(2): 138-150. http://dx.doi.org/10.1061/(ASCE)CO.1943-7862.0000118

Jingzhu, X.; Ng, T. S. 2013. Multiobjective Bayesian network model for public-private partnership decision support, Journal of Construction Engineering and Management 139(9): 1069-1081.

http://dx.doi.org/10.1061/(ASCE)CO.1943-7862.0000695

Laurinavičius, A.; Grigonis, V.; Ušpalytė-Vitkūnienė, R.; Ratkevičiūtè, K.; Čygaite, L.; Skrodenis, E.; Antov, D.; Smirnovs, J.; Bobrovaitė-Jurkonè, B. 2012. Policy instruments for managing EU road safety targets: road safety impact assessment, The Baltic Journal of Road and Bridge Engineering 7(1): 60-67.

http://dx.doi.org/10.3846/bjrbe.2012.09

Liu, T.; Wilkinson, S. 2014. Large-scale public venue development and the application of Public-Private Partnerships (PPPs), International Journal of Project Management 32: 88-100. http://dx.doi.org/10.1016/j.ijproman.2013.01.003

Meda, F. 2012. Land value capture finance for transport accessibility: a review, Journal of Transport Geography 25: 154-161. http://dx.doi.org/10.1016/j.jtrangeo.2012.07.013

Nejad, F. M.; Azarhoosh, A. R.; Hamedi, G. H. 2013. The effects of using recycled concrete on fatigue behavior of hot mix asphalt, Journal of Civil Engineering and Management 19(Supplement 1): S61-S68. http://dx.doi.org/10.3846/13923730.2013.801892

Radziszewski, P.; Kowalski, K. J.; Król, J. B.; Sarnowski, M.; Piłat, J. 2014. Quality assessment of bituminous binders based on the viscoelastic properties: Polish experience, Journal of Civil Engineering and Management 20(1): 111120. http://dx.doi.org/10.3846/13923730.2013.843586

Sivilevičius, H.; Vansauskas, V. 2013. Research and evaluation of ruts in the asphalt pavement on Lithuanian highways, Journal of Civil Engineering and Management 19(5): 609-621. http://dx.doi.org/10.3846/13923730.2013.817481

Subramanian, A.; Brown, B.; Wolf, A. 2012. Across the waters. Facing the risk of coorporation in international waters, The World Bank. Water Paper, 1-85.

Vaitkus, A.; Laurinavičius, A.; Oginskas, R.; Motiejūnas, A.; Paliukaite, M.; Barvidienè, O. 2012. The road of experimental pavement structures: Experience of five years operation, The Baltic Journal of Road and Bridge Engineering 7(3): 220-227. http://dx.doi.org/10.3846/bjrbe.2012.30

Wang, F.; Ding, L. Y.; Luo, H. B.; Love, P. E. D. 2014. Probabilistic risk assessment of tunneling-induced damage to existing Properties, Expert Systems with Applications 41(4): 951-961. http://dx.doi.org/10.1016/j.eswa.2013.06.062

Xu, Y.; Chan, A. P. C.; Yeung, J. F. Y. 2010. Developing a fuzzy risk allocation model for PPP projects in China, Journal of Construction Engineering and Management 136(8): 894-903.

http://dx.doi.org/10.1061/(ASCE)CO.1943-7862.0000189

Yazdani-Chamzini, A. 2014. Proposing a new methodology based on fuzzy logic for tunnelling risk assessment, Journal of Civil Engineering and Management 20(1): 82-94. http://dx.doi.org/10.3846/13923730.2013.843583 
Zavadskas, E. K.; Turskis, Z.; Tamošaitienè, J. 2010. Risk assessment of construction projects, Journal of Civil Engineering and Management 16(1): 33-46. http://dx.doi.org/10.3846/jcem.2010.03

Rūta RUDŽIANSKAITÉ-KVARACIEJIENĖ. PhD Student of Kaunas University of Technology, Faculty of Civil Engineering and Architecture, Department of Civil Technology. She received the M.S. degree in civil engineering from Kaunas University of Technology, Lithuania, in 2007. Main research interests: construction project management, investment projects, effectiveness modelling, random forests.

Rasa APANAVIČIENĖ. Assoc. Prof. of the Department of Civil Engineering Technologies at Kaunas University of Technology. $\mathrm{PhD}$ in Civil Engineering from Kaunas University of Technology in 2002. Main research interests: construction project management, investment projects, strategic management and effectiveness modelling, neural networks.

Adas GELŽINIS. Adas Gelzinis received the M.S. degree in electrical engineering from Kaunas University of Technology, Lithuania, in 1995. He received the $\mathrm{PhD}$ degree in computer science from the same university, in 2000 . He is a professor in the Department of Electrical Power Systems at Kaunas University of Technology. His research interests include artificial neural networks, kernel methods, pattern recognition, signal and image processing, texture classification. 